\title{
IN-VITRO LABELLING OF OVINE ADIPOSE-DERIVED MESENCHYMAL STEM CELLS (OADMSCS) AND TRACKING USING MRI TECHNIQUE
}

\author{
Ravi Gnanam Gnanadevi ${ }^{1}$, Geetha Ramesh ${ }^{1}$, Thandavan Arthanari Kannan ${ }^{2}$, \\ Benjamin Justin William², Manoharan Parthiban ${ }^{3}$, Gnanasigamani Sathyan ${ }^{4}$ \\ ${ }^{1}$ Department of Veterinary Anatomy, Madras Veterinary College, \\ Tamil Nadu Veterinary and Animal Sciences University, India \\ ${ }^{2}$ Centre for Stem Cell Research and Regenerative Medicine, Madras Veterinary College, \\ Tamil Nadu Veterinary and Animal Sciences University, India \\ ${ }^{3}$ Department of Animal Biotechnology, Madras Veterinary College, \\ Tamil Nadu Veterinary and Animal Sciences University, India \\ ${ }^{4}$ Department of Radiodiagnosis, Government Stanley Medical College, Chennai, India
}

Received 27 November 2016; Received in revised form 13 February 2017; Accepted 15 April 2017

\begin{abstract}
To understand the mechanisms standing behind a successful stem cell-based therapy, the monitoring of transplanted cell's migration, homing as well as the engraftment efficiency and functional capability in-vivo has become a critical issue. The present study was designed to track the labelled oADMSCs in-vitro and its visualization through MRI technique. oADMSCs from passage 4 (P-4) to passage 6 (P-6) were labelled with superparamagnetic iron oxide (SPIO) conjugated with rhodamine (Molday Ion Rhodamine-B - MIRB) at the concentration of $25 \mu \mathrm{g} \mathrm{Fe} / \mathrm{ml}$ in DMEM. Internalized MIRB was observed under fluorescent microscope after $72 \mathrm{hrs}$ of incubation. Labelled oADMSCs showed Prussian Blue positive reaction demonstrating the iron uptake of the cells. The viability of the MIRB-labelled oADMSCs ranged between 9899 per cent and Trypan blue exclusion test showed no significant difference in viability between labelled and unlabelled oADMSCs. MR signal in control group of cells was similar to that of water. MR signals or fluorescence in MIRB-labelled cells decreased with increasing concentrations of iron. The T2 weighted images of MIRB-labelled oADMSCs increased with increasing concentrations of SPIOs. The MIRB was found to be nontoxic, and did not affect proliferation capacity in-vitro.
\end{abstract}

Key words: ovine, mesenchymal stem cells, in-vitro MIRB labelling, MRI imaging

\section{INTRODUCTION}

Several types of stem cells have been proposed for therapies, with the basis of their potential benefit ranging from providing nutritive support for injured host tissue, as a reservoir for growth factors and as replacement neurons for host cells lost to injury or disease. An underlying prerequisite for all of these

Corresponding author: Prof. Thandavan Arthanari Kannan, $\mathrm{PhD}$ E-mail address: kanns2000@gmail.com

Present address: Centre for Stem Cell Research and Regenerative

Medicine, Madras Veterinary College, Tamil Nadu Veterinary and Animal

Sciences University, Chennai - 600007, India

Phone: +91-9841565079 Fax: +044-25362787

Copyright: (C) 2017 Gnanadevi R.G.This is an open-access article published under the terms of the Creative Commons Attribution License which permits unrestricted use, distribution, and reproduction in any medium, provided the original author and source are credited.

Competing Interests: The authors have declared that no competing interests exist.

Available Online First: 22 May 2017

Published on: 15 October 2017

https://doi.org/10.1515/macvetrev-2017-0018 goals is survival and appropriate localization of the transplanted stem cells (1). The successful use of mesenchymal stem cells in the treatment requires a method to detect transplanted cells in-vivo in order to understand the mechanisms of transplanted cell's migration, homing as well as the engraftment efficiency and functional capability $(2,3,4)$.

Magnetic resonance imaging (MRI) is one of the ideal tracking methods, because it is noninvasive, high resolution and allows tracking in four dimensions including time, though it requires a suitable contrast agent to be loaded to the tracked cells. One of the most commonly used in stem cell tracking is a group of agents known as magnetic nanoparticles $(5,6,7)$. Molday ION Rhodamine-B ${ }^{\text {TM }}$ (MIRB) is a new superparamagnetic iron oxide (SPIO) contrast agent specifically formulated for cell labelling, which is readily internalized by 
non-phagocytic cells. It can be visualized by both MRI and fluorescence microscopy and it can assess the potential for imaging and monitoring of MSCs transplantation (8).

\section{MATERIAL AND METHODS}

In the present study, oADMSCs were isolated from perirenal fat of sheep according to the method published previously, using type I collagenase (SIGMA ${ }^{\circledR}$ Cat. No. CO130). The cells were cultured using DMEM with 10\% FBS and 1\% antibioticantimycotic solution. In the primary culture (P-0), $70 \%$ confluency was observed 17 days post incubation. Whereas, in subsequent passages the cells grew at a faster rate and $70 \%$ confluency was noticed in 3 days. Then the oAMSCs were subcultured using $0.25 \%$ typsin (9).

Plates of oADMSCs, from passage 4 to passage 6 with $70 \%$ confluency were used for labelling.

\section{Preparation of labelling solution}

MIRB (BioPAL Inc.) was added to the medium (DMEM $+10 \%$ FBS $+1 \%$ antibiotics-antimycotic) at the concentration of $25 \mu \mathrm{g} \mathrm{Fe} / \mathrm{ml}$ as per $(8,10)$. Labelling solution was filtered with syringe filter before use.

\section{Labelling of oADMSCs}

The oADMSCs were labelled by culturing the cells in the labelling solution containing $25 \mu \mathrm{g} \mathrm{Fe} / \mathrm{ml}$ $(8,10)$. The culture plates were incubated at $37^{\circ} \mathrm{C}$ with $5 \% \mathrm{CO}_{2}$. The spent medium was replaced by a fresh medium containing MIRB at every $24 \mathrm{hrs}$ (1). The labelled oADMSCs were examined under fluorescent microscope (Olympus) to observe the integration of MIRB (8).

The labelled oADMSCs were assessed for intracellular MIRB distribution, viability and in-vitro MRI tracking.

\section{Intracellular MIRB analysis}

The unlabelled and MIRB-labelled oADMSCs (72hrs of MIRB incubation) of P-4, P-5 and P-6 were fixed with biopal fixative and further subjected to Prussian blue staining to demonstrate the iron uptake of the cells (11).

\section{Cell viability}

Trypan blue exclusion test was used for assessment of cell viability by using the formula: unstained cells / total number of cells x 100 as per
(12). The viability of labelled and unlabelled cells was analyzed statistically by a chi-square test as per standard protocol (13).

\section{In-vitro MRI detection of iron}

For in-vitro MRI evaluation of MIRB-labelled oADMSCs, phantom models containing MSCs in agar were used. Phantoms were constructed as groups of $10 \mathrm{ml}$ sample tubes (borosilicate glass culture tubes) containing MIRB-labelled oADMSCs suspended in agar. Differences between the MIRB-labelled oADMSCs and unlabelled oADMSCs were studied in MR relaxation time. MIRB-labelled oADMSCs (72 hrs MIRB incubation) and unlabelled oADMSCs were centrifuged into a pellet and resuspended with melted $0.5 \%$ agarose and sandwiched between two layers of $0.5 \%$ plain agar (Fig. 1). Each tube contained $1 \times 10^{6}$ cells. The tubes were imaged with an eight-channel phased-array head coil on a clinical 1.5 T Siemens Symphony MRI unit $(8,14)$.

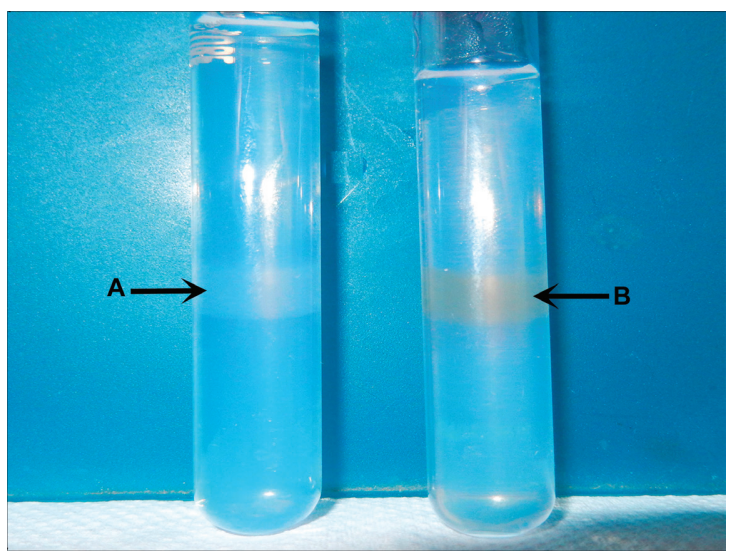

Figure 1. Unlabelled (A) and MIRB-labelled (B) oADMSCs sandwiched between two layers of $0.5 \%$ plain agar

\section{RESULTS}

In the present study, no fluorescence of MIRB could be detected within the cytoplasm of oADMSCs of P-4, P-5 and P-6 after 24 hrs and $48 \mathrm{hrs}$ of post incubation. However, $72 \mathrm{hrs}$ post incubation, internalized MIRB was observed as red colored fluorescent clusters in oADMSCs of P-4 (Fig. 2), P-5 (Fig. 3) and P-6 (Fig. 4). This indicated the intracytoplasmic integration of iron nanoparticles after $72 \mathrm{hrs}$ of incubation. 


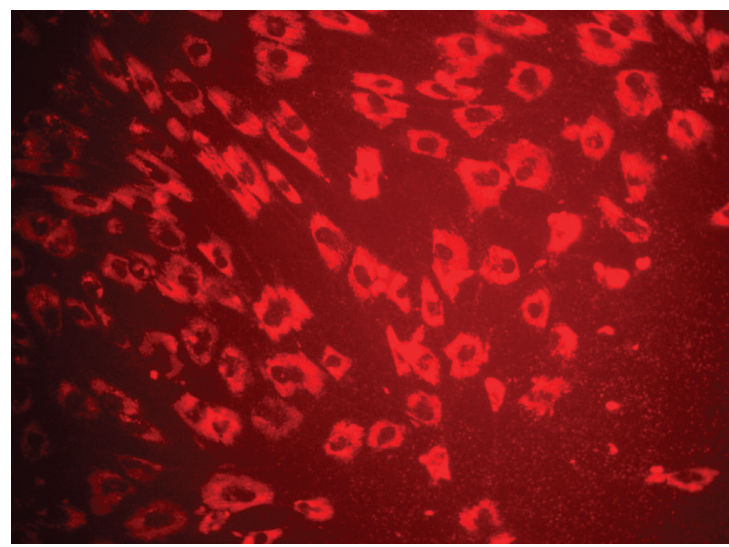

Figure 2. Micrography of MIRB labelled ADMSCs (P-4 level) $72 \mathrm{hrs}$ of post incubation. MIRB; bar $=200 \mathrm{x}$

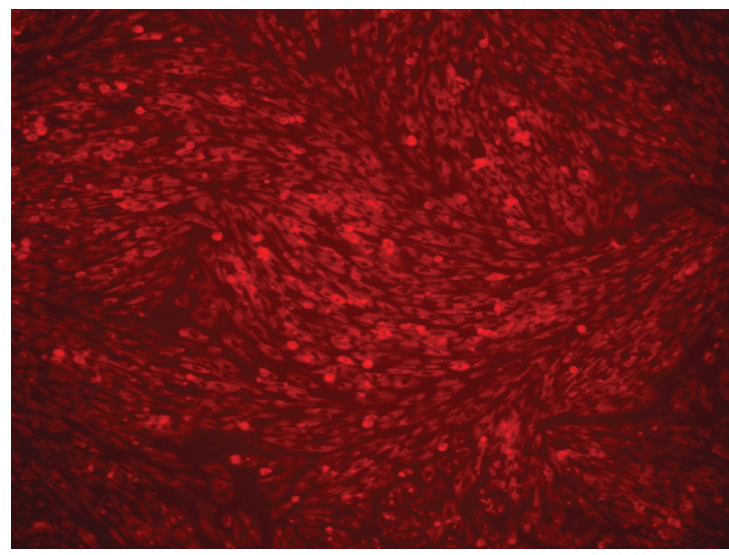

Figure 3. Micrography of MIRB labelled ADMSCs (P-5 level) $72 \mathrm{hrs}$ of post incubation. MIRB; bar $=200 \mathrm{x}$

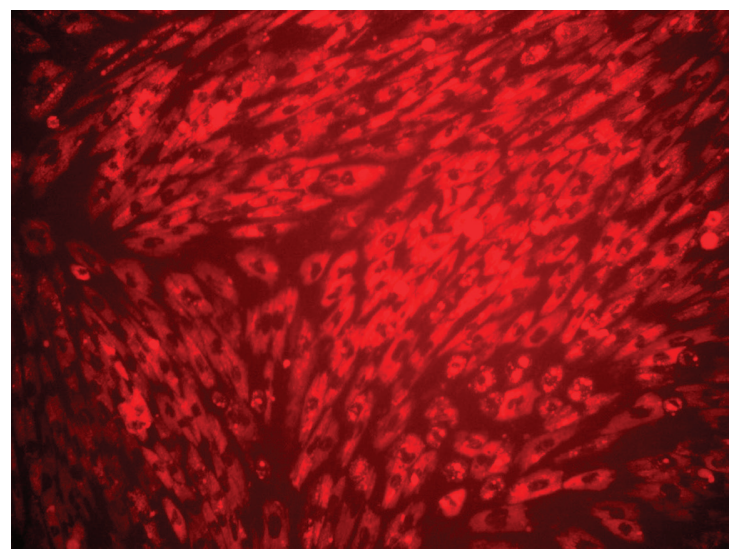

Figure 4. Micrograph of MIRB-labelled ADMSCs (P-6 level) $72 \mathrm{hrs}$ of post incubation. MIRB; bar $=200 \mathrm{x}$

\section{Intracellular MIRB analysis}

The MIRB-labelled oADMSCs of passages 4, 5 and 6 showed positive intracytoplasmic inclusion blue reaction to Prussian blue (Fig. 5), whereas unlabelled cells did not show positive reaction (Fig. 7).

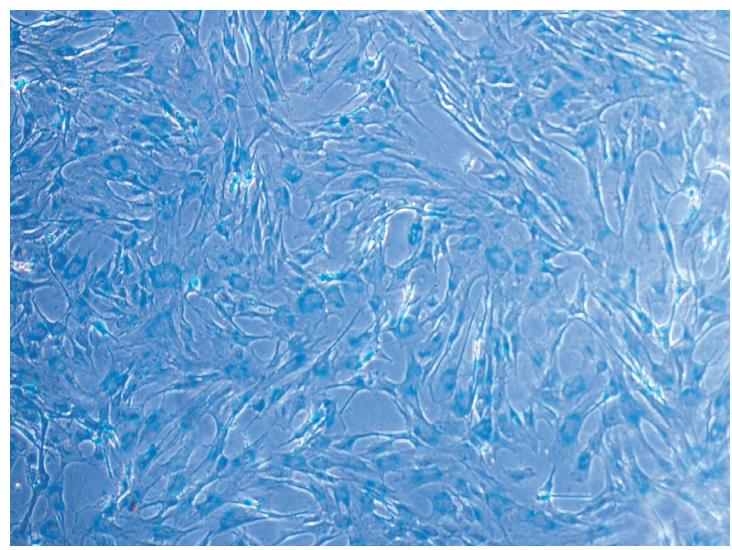

Figure 5. Micrograph of MIRB-labelled oADMSCs showing positive intracytoplasmic blue inclusion. Prussian blue; bar $=200 \mathrm{x}$

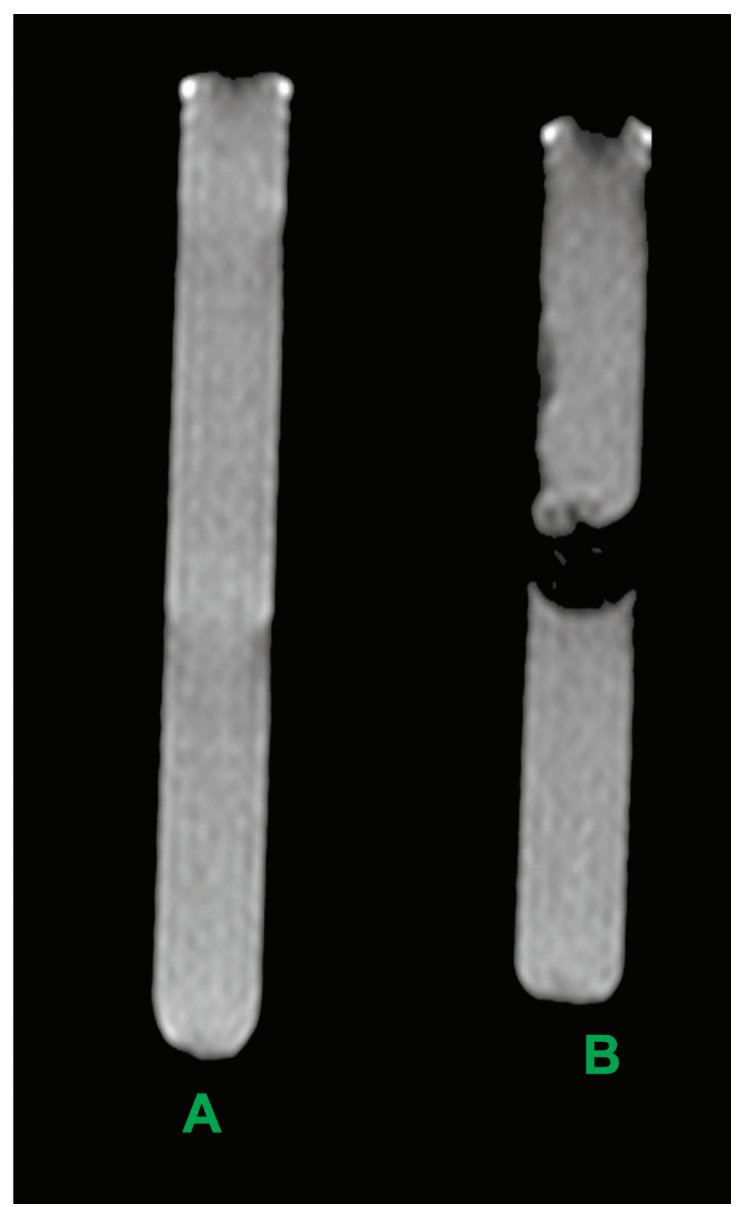

Figure 6. MRI image of unlabelled (A) and MIRBlabelled (B) ADMSCs sandwiched between two layers of $0.5 \%$ plain agar 
Table 1. Viability in MIRB labelled oADMSCs

\begin{tabular}{|c|c|c|c|c|c|}
\hline & & $\begin{array}{l}\text { Viable cells } \\
\quad \text { (in } 1^{6} \text { ) }\end{array}$ & $\begin{array}{l}\text { Non-viable cells } \\
\quad \text { (in } 1^{6} \text { ) }\end{array}$ & $\begin{array}{l}\text { Total cells } \\
\text { (in } 1^{6} \text { ) }\end{array}$ & $\%$ of viable cells \\
\hline \multirow{3}{*}{ P4 } & labelled & 2.94 & 0.046 & 2.99 & 98.32 \\
\hline & unlabelled & 3.10 & 0.048 & 3.14 & 98.73 \\
\hline & & $\left(\chi^{2}\right)=$ & \multicolumn{2}{|c|}{$1.764272677^{\mathrm{NS}}$} & \\
\hline \multirow{3}{*}{ P5 } & labelled & 2.90 & 0.034 & 2.93 & 98.97 \\
\hline & unlabelled & 2.95 & 0.034 & 2.98 & 98.89 \\
\hline & & $\left(\chi^{2}\right)=$ & \multicolumn{2}{|c|}{$0.105417701^{\mathrm{NS}}$} & \\
\hline \multirow{3}{*}{ P6 } & labelled & 2.60 & 0.026 & 2.62 & 99.24 \\
\hline & unlabelled & 3.15 & 0.032 & 3.18 & 98.06 \\
\hline & & $\left(\chi^{2}\right)=$ & \multicolumn{2}{|c|}{$0.156252901^{\mathrm{NS}}$} & \\
\hline
\end{tabular}

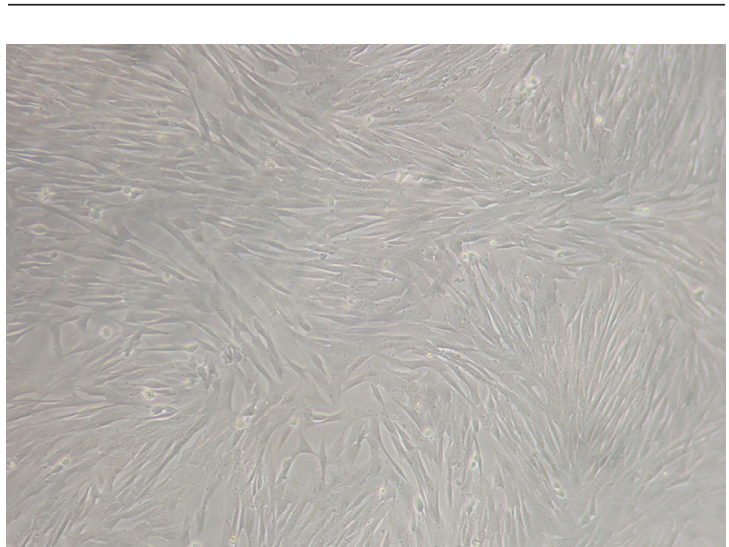

Figure 7. Micrography of unlabelled ADMSCs (Control) $72 \mathrm{hrs}$ of post incubation; bar $=200 \mathrm{x}$

\section{Viability assay}

In the present study, $98.4 \%$ of oADMSCs were viable after $72 \mathrm{hr}$ incubation with MIRB in P-4. It was observed that $98.8 \%$ cells in P-5 and 98.9 $\%$ cells in P-6 were viable in $72 \mathrm{hrs}$ of incubation (Table 1).

No significant difference was observed between the viability of MIRB-labelled oADMSCs and unlabelled oADMSCs (Table 1). The viability of the MIRB-labelled oADMSCs ranged between 98-99\%.

\section{MRI}

In the present study, MR signal intensity was lower in MIRB-labelled ADMSCs (P-4, P-5, P-6) when compared to control (unlabelled) group of cells (Fig. 6). No significant difference was observed based on MR signal intensity between the oADMSCs at P-4, P-5, P-6.

Emission of MR signals in labelled cells indicated the successful bio-imaging at cellular level in visualizing oADMSCs in-vitro.

\section{DISCUSSION}

\section{Intracellular MIRB analysis}

In the present study, intracytoplasmic integration of iron nanoparticle occured after $72 \mathrm{hrs}$ of incubation. A similar finding was observed with Prussian blue staining in MIRB labelled human MSCs, human cervical carcinoma (HeLa) cells and CG-4 cells (15). The effects of iron oxide-poly (L-lactide) nanoparticles was studied in human BM-MSCs (15); in Cynomolgus monkey BMMSCs labeled with MIRB $(8,10)$; in rat BM-MSCs (16); in human neural progenitor cells labeled with $\operatorname{MIRB}(1,12)$.

\section{Viability assay}

In the present study, viability of the MIRB labelled oADMSCs ranged between 98-99\%, which is in accordance to (17) who worked on sheep BMMSCs which consisted of both haematopoietic and mesenchymal stem cell population in contrast to adipose tissue which included only 
the mesenchymal stem cell population. However, in cynomolgus monkey BM-MSCs at MIRB concentrations of up to $30 \mu \mathrm{g} \mathrm{Fe} / \mathrm{ml}$, viability (95$99 \%$ was not significantly different compared with unlabelled MSCs (98-100 \%) (8). For higher labelling concentrations, above $30 \mu \mathrm{g} \mathrm{Fe} / \mathrm{ml}$, viability monotonically decreased and reached a value of $78.8 \%$ at MIRB labelling concentrations of $100 \mu \mathrm{g} \mathrm{Fe} / \mathrm{ml}$.

\section{MRI}

In the present study, emission of MR signals in labelled cells indicated the successful bio-imaging at cellular level in visualizing oADMSCs in-vitro $(18,19)$. T2* images of labelled oADMSCs in the present study are in accordance with results published previously $(20,21)$

\section{CONCLUSION}

Labelling the oADMSC using MIRB does not affect the viability and proliferation of the cells in-vitro between passages when the contrast agent is used at minimal level $(25 \mu \mathrm{g} \mathrm{Fe} / \mathrm{ml})$. The viability is estimated by Trypan blue exclusion test and proliferative capacity is assessed based on the percentage of cell confluence between passages. The present in-vitro study on MRI tracking of MIRB-labelled cells will serve as a model for in-vivo study.

\section{ETHICAL APPROVAL}

The present study was carried out after getting approved by the Institutional Ethical Committee for Stem Cell Research and Regenerative Medicine of Tamil Nadu Veterinary and Animal Sciences University.

\section{CONFLICT OF INTEREST STATEMENT}

The authors declared that they have no potential conflict of interest with respect to the authorship and/or publication of this article

\section{ACKNOWLEDGEMENT}

The authors acknowledge the Madras Veterinary College Dean for providing Financial support to carry out this project.

\section{REFERENCES}

1. Shen, W.B., Plachez, C., Chan, A., Yarnell, D., Puche, A.C, Fishman, P.S., Yarowsky, P. (2013). Human neural progenitor cells retain viability, phenotype, proliferation, and lineage differentiation when labeled with a novel iron oxide nanoparticle, Molday ION Rhodamine B. International Journal of Nanomedicine 8, 4593-4600.

PMid:24348036 PMCid:PMC3849141

2. Daldrup-Link, H.E., Rudelius, M., Piontek, G., Rudelius, M., Piontek, G., Metz, S., Bräuer, R., Debus, G., Corot, C., Schlegel, J., Link, T. M., Peschel, C., Rummeny, E.J., Oostendorp, R.A. (2005). Migration of iron oxide-labeled human hematopoietic progenitor cells in a mouse model: in vivo monitoring with 1.5 -T MR imaging equipment. Radiology 234, 197-205.

https://doi.org/10.1148/radiol.2341031236

PMid:15618382

3. Bussolati, B., Camussi, G. (2006). Adult stem cells and renal repair. J Nephrol. 19, 706-709.

PMid:17173241

4. Henning, T.D., Wendland,M.F., Golovko,D., Sutton,E.J., Sennino, B., Malek, F., Bauer, J.S., McDonald, D.M., Daldrup-Link, H. (2009). Relaxation effects of ferucarbotran-labeled mesenchymal stem cells at $1.5 \mathrm{~T}$ and 3T: discrimination of viable from lysed cells. Magn Reson Med. 62, 325-32.

https://doi.org/10.1002/mrm.22011

PMid:19353670 PMCid:PMC2931823

5. Hoehn, M., Kustermann, E., Blunk, J., Wiedermann, D., Trapp, T., Wecker, S., Focking, M., Arnold, H., Hescheler, J., Fleischmann, B.K., Schwindt, W., Bührle, C. (2002). Monitoring of implanted stem cell migration in vivo: a highly resolved in vivo magnetic resonance imaging investigation of experimental stroke in rat. Proc Natl Acad Sci. 99, 16267-16272. https://doi.org/10.1073/pnas.242435499 PMid:12444255 PMCid:PMC138600

6. Guzman, R., Uchida, N., Bliss, T.M., He, D., Christopherson, K.K., Stellwagen, D., Capela, A., Greve, J., Malenka, R.C., Moseley, M.E., Palmer, T.D., Steinberg, G.K. (2007). Long-term monitoring of transplanted human neural stem cells in developmental and pathological contexts with MRI. Proc Natl Acad Sci USA. 104 (24): 10211-10216. https://doi.org/10.1073/pnas.0608519104 PMid:17553967 PMCid:PMC1891235

7. Sykova, E., Jendelova, P. (2007). Migration, fate and in-vivo imaging of adult stem cells in the CNS. Cell Death Differ. 14, 1336-1342.

https://doi.org/10.1038/sj.cdd.4402140 PMid:17396130 
8. Addicott, B., Willman, M., Rodriguez, J., Padgett, K., Han, D., Berman, D., Hare, J.M., Kenyon, N.S. (2011). Mesenchymal stem cell labeling and in vitro MR characterization at $1.5 \mathrm{~T}$ of new SPIO contrast agent: Molday ION Rhodamine $\mathrm{B}^{\mathrm{TM}}$ Contrast Media. Mol Imaging 6, 718.

https://doi.org/10.1002/cmmi.396

PMid:20690161 PMCid:PMC4410881

9. Guercio, A., Marco, A. D., Casella, S., Cannella, V., Russotto, L., Purpari, G., Bella, S. D., Piccione, G. (2012). Production of canine mesenchymal stem cells from adipose tissue and their application in dogs with chronic osteoarthritis of the humeroradial joints. Cell Biol. Int. 36, 189-194.

https://doi.org/10.1042/CBI20110304

PMid:21936851

10. Ren, Z.H., Wang, J.Y., Zou, C.L., Guan, Y.Q., Zhang, Y.A. (2011). Labeling of cynomolgus monkey bone marrow-derived mesenchymal stem cells for cell tracking by multimodality imaging. Sci China Life Sci. 54, 981-987.

https://doi.org/10.1007/s11427-011-4239-x PMid:22173303

11. Natalio, F., Wiese, S., Friedrich, N., Werner, P., Tahir, M.N. (2014). Localization and characterization of ferritin in Demospongiae: a possible role on spiculogenesis. Mar Drugs. 12 (8): 4659-4676.

https://doi.org/10.3390/md12084659

PMid:25153764 PMCid:PMC4145336

12. Nan, H., Huang, J., Li, H., Li. Q., Liu, D. (2013). Assessment of biological characteristics of adipose tissue derived stem cells co labeled with Molday ION Rhodamine $\mathrm{B}^{\mathrm{TM}}$ and green fluorescent protein in-vitro. Mol Med Rep. 8, 1446-1452.

PMid:24065138

13. Snedecor, C.W., Cochran, W.G. (1994). Statistical methods. 9th Ed., Iowa state University press, Ames, Iowa.

14. Fan, J., Tan, Y., Jie, L., Wu, X., Yu, R., Zhang, M. (2013). Biological activity and magnetic resonance imaging of superparamagnetic iron oxide nanoparticles-labeled adipose-derived stem cells. Stem Cell Res Ther. 4, 44.

https://doi.org/10.1186/scrt191

PMid:23618360 PMCid:PMC3706947

15. Schmidtke-Schrezenmeier, G., Urban, M., Musyanovych, A., Nder, V.M.A., Rojewski, M., Fekete, N., Menard, C., Deak, E., Tarte, K., Rasche, V.,
Landfester, K., Schrezenmeier, H. (2011). Labeling of mesenchymal stromal cells with iron oxide - poly (L -lactide) nanoparticles for magnetic resonance imaging: uptake, persistence, effects on cellular function and magnetic resonance imaging properties. Cytotherapy 13, 962-975. https://doi.org/10.3109/14653249.2011.571246 PMid:21492060 PMCid:PMC3172145

16. Guo, R.M.,Cao, N.,Zhang, F., Wang, Y.R., Wen, X.H., Shen J., Shuai, X.T. (2012). Controllable labelling of stem cells with a novel superparamagnetic iron oxide-loaded cationic nanovesicle for MR imaging. Eur Radiol. 22 (11): 2328-2337. https://doi.org/10.1007/s00330-012-2509-Z PMid:22653284

17. Gnanadevi, R., Geetha Ramesh, Kannan, T. A., Justin William, B., Sathyan G., Hayath Basha, S. (2016). In-vitro study of MIRB labeled ovine bone marrow derived mesenchymal stem cells by MRI Technique. International Journal of Livestock Research 6 (9): 38-48. https://doi.org/10.5455/ijlr.20160917082803

18. Guthi, J.S., Yang, S.G., Huang, G., Li, S., Khemtong, C., Kessinger, C., Peyton, M., Minna, J., Brown, K.C., Gao, J. (2010). MRI-visible micellar nanomedicine for targeted drug delivery to lung cancer cells. Mol Pharm. 7, 32-40. https://doi.org/10.1021/mp9001393 PMid:19708690 PMCid:PMC2891983

19. Li, L., Jiang, W., Luo, K., Song, H., Lan, F., Wu, Y., Gu, Z. (2013). Superparamagnetic iron oxide nanoparticlesas MRI contrast agents for non-invasive stem cell labeling and tracking. Theranostics 3 (8): 595-615.

https://doi.org/10.7150/thno.5366 PMid:23946825 PMCid:PMC3741608

20. Shapiro, E.M, Skrtic, S., Sharer, K., Hill, J. M., Dunbar, C. E., Koretsky, A.P. (2004). MRI detection of single particles for cellular imaging. Proc Natl Acad Sci. 101, 10901-10906.

https://doi.org/10.1073/pnas.0403918101

PMid:15256592 PMCid:PMC503717

21. Salamon, J., Wicklein, D., Didié, M., Lange, C., Schumacher, U., Adam, G., Peldschus, K. (2014). Magnetic resonance imaging of single co-labeled mesenchymal stromal cells after intracardial injection in mice. Fortschr Röntgenstr. 186, 367-376. https://doi.org/10.1055/s-0034-1366097 PMid:24683169 